\title{
The potential protective role of flaxseed extract on ventral prostate in a rat model of streptozotocin-induced diabetes: A histological and immunohistochemical study
}

\author{
Amira A Kassab
}

Department of Histology, Faculty of Medicine, Tanta University

\begin{abstract}
Background: Diabetes mellitus is a chronic disorder that can affect the reproductive system leading to fertility dysfunction. The prostate plays an important role in the reproduction and it is a frequent target for diabetic complications. Flaxseed is a promising alternative in many chronic diseases due to its health benefits. It has a proposed role in controlling diabetes due to its wide pharmacological activities.

Aim: Evaluation of the possible protective role of flaxseed extract on the ventral prostate gland of diabetic rats.

Materials and Methods: Fifty adult male albino rats were used as a control group and experimental group that received a single intra-peritoneal injection of streptozotocin $(60 \mathrm{mg} / \mathrm{kg})$. The experimental rats with confirmed diabetes mellitus were subdivided into: diabetic group that kept without treatment and diabetic-flaxseed group ( $400 \mathrm{mg} / \mathrm{kg} / \mathrm{day}$ orally). After four weeks, specimens of the ventral prostate lobes were processed for histological and immunohistochemical study using antibodies against $\mathrm{Bcl}-2, \alpha$-smooth muscle actin and androgen receptor.

Results: In comparison with the control, specimens of the diabetic group showed glandular epithelial atrophy with thickening of the fibromuscular stroma. Reduced epithelial height and a statistically significant decrease in Bcl2 immunoexpression were observed in the epithelial cells. A statistically significant increase in the collagen fibers and $\alpha$-SMA immunoexpression was seen in the stroma. Androgen receptor immunoreactivity was significantly decreased in both epithelial and stromal cells. In contrast, minimal changes appeared in diabetic-flaxseed group that received flaxseed extract.

Conclusion: Diabetes induced structural alterations in the ventral prostate gland of rats. Administration of flaxseed extract attenuated these effects and partially preserved the glandular structure.
\end{abstract}

Received: 30 November 2018, Accepted: 29 January 2019

Key Words: Diabetes Mellitus, Flaxseed, Prostate gland.

Corresponding Author: Amira A. kassab, MD, Histology Department, Faculty of Medicine, Tanta University, 31527 Tanta, Egypt, Tel.: +20 106697635, E-mail: Amirakassab80@yahoo.com

ISSN: 1110-0559, Vol. 42, No. 2

\section{INTRODUCTION}

Diabetes mellitus (DM) is a worldwide chronic metabolic and endocrine disorder affecting over 350 million people. It is rapidly increasing out of proportion due to modern lifestyle habits ${ }^{[1]}$. Its adverse effects on male sexual and reproductive organs are well established. Impotency, impaired spermatogenesis, reduced sperm count and motility and prostatic complications are commonly encountered in patient with diabetes ${ }^{[2,3]}$. Oxidative stress associated with hyperglycemia has been postulated to be responsible for development of these complications ${ }^{[4]}$.

The prostatic fluid plays a major role in maintenance of sperm quality. Thirty five percent of diabetic patients suffer from infertility due to reduced sperm quality. The prostate contributes to diabetic male infertility due to reduced volume of the prostatic secretion or increased semen viscosity during the gland pathology. The increased viscosity leads to impaired semen parameters especially sperm motility. The association between diabetes and prostate gland pathology has been reported in several studies. It was attributed to metabolic disturbance or changes in sex hormone levels in diabetic patients ${ }^{[5]}$. Previous study reported that type $2 \mathrm{DM}$ is associated with low serum testosterone and prostate specific antigen and increased prostate volume. Moreover, inhibition of growth of the prostate stem epithelial cells occurs due to reduction of insulin ${ }^{[6,7]}$.

The function and survival of epithelium of prostate gland are dependent on androgens which are affected by DM. The biological effects of these hormones are mediated by androgen receptors. In rat, the androgen receptors are found in all lobes of the prostate gland mainly in the epithelial cells and the surrounding stromal cells ${ }^{[6,8]}$. Moreover, the prostatic stroma directly affects the epithelial cell behavior (growth and function) under androgen control and is activated as a response to prostate injury ${ }^{[9]}$.

Flaxseed or linseed comes from an annual herb called flax plant. It has been used in many countries as food or 
medicines in various forms as flour, oil and seed. Recently, the flaxseed is being a focus of increased interest in the field of disease research due to the health benefits of its biologically active compounds ${ }^{[10]}$. The seed is a good source of dietary fibers, $\alpha$-linolenic acid and lignans (bioactive polyphenolic phytochemicals). It helps effectively in controlling many chronic disorders as cardiovascular diseases, strokes, cancers and diabetes ${ }^{[11,12]}$. Previous clinical study reported that regimen diet containing flaxseed in supplemented bakery for 12 weeks decreases the blood glucose and lipid profile in type $2 \mathrm{DM}^{[13]}$.

Based on the previous data, this work was designed to study the effect of streptozotocin-induced diabetes on the ventral prostate gland in adult albino rats and to evaluate the potential role of flaxseed extract in ameliorating the diabetic effect on the prostate employing different histological and immunohistochemical methods.

\section{MATERIALS AND METHODS}

\section{Chemicals}

1. Streptozotocin: a white powder in a glass bottle (1gram) obtained from Sigma Chemical Co. (CAS Number 18883-66-4). It is used to induce type I diabetes mellitus.

2. Flaxseeds: They were purchased as a pouch of 250 grams of organic brown flax seeds with a brand name Markal (Part number: GRALBC250, Markal, Snacks). The seeds were grinded and the powder was used for preparation of the crude extract. About 100 grams of the flaxseeds powder was soaked in 2 liters of $70 \%$ aqueous methanol solution for 5 days. After 5 days, supernatant was separated and the remaining plant material was again soaked in $70 \%$ aqueous methanol solution for another 5 days. The supernatant was again separated. The filtrates for the two collections were concentrated by using a rotary evaporator to get the crude extract ${ }^{[14]}$.

\section{The experimental design}

This study was approved by the Research Ethics Committee of Faculty of Medicine, Tanta University, Egypt and was performed in accordance with Guidelines for Ethical Conduct in the care and Use of all animals (Approval code: 32637/10/18).

The experiment was designed by dividing 50 adult male albino rats weighing 200-255 grams each into 2 groups:

1. Group I (control group): included 30 rats that were subdivided into 3 equal subgroups: the first (subgroup IA) received no treatment, the second (subgroup IB) received a single intraperitoneal (IP) injection of $0.2 \mathrm{ml}$ of $0.1 \mathrm{M}$ sodium citrate and the third (subgroup IC) received flaxseed extract at a dose of $400 \mathrm{mg} / \mathrm{kg} /$ day orally.

2. Group II (experimental group): included 20 rats that received a single IP injection of $60 \mathrm{mg} / \mathrm{kg}$ streptozotocin dissolved in sodium citrate just before injection ${ }^{[15]}$. The blood glucose levels were measured three days after the streptozotocin injection by a blood glucose meter (Accu-Check Advantage, Roche, Germany). Animals with blood glucose level of $(\geq 250 \mathrm{mg} / \mathrm{dl})$ were considered diabetic $^{[16]}$. They were rearranged into two equal subgroups (10 rats each):

A. Subgroup IIA (diabetic group): that was kept without additional treatment.

B. Subgroup IIB (diabetic-flaxseed group): that received flaxseed extract at a dose of $400 \mathrm{mg} / \mathrm{kg} /$ day orally ${ }^{[15]}$.

After 4 weeks, all rats were anaesthetized by an IP injection of pentobarbital in a dose of $50 \mathrm{mg} / \mathrm{kg}^{[17]}$. The ventral lobe of the prostate gland was dissected out and processed for the light microscopic examination.

For histological study: The prostate specimens were fixed in $10 \%$ neutral-buffered formalin, washed, dehydrated, cleared and then embedded in paraffin. Sections of $5 \mu \mathrm{m}$ thickness were stained with haematoxylin and eosin $(\mathrm{H} \& \mathrm{E})^{[18]}$ and Mallory's trichrome stain ${ }^{[19]}$.

For immunohistochemistry: Sections of $5 \mu \mathrm{m}$ thickness were dewaxed, rehydrated, and washed with phosphate buffered saline (PBS). The sections were incubated in a humid chamber with the primary anti-Bcl 2 antibody (1:1000 dilution $^{[20]}$ ) (rabbit polyclonal antibody, ab59348, Abcam), anti-androgen receptor (AR) antibody (1:100 dilution $\left.{ }^{[21]}\right)$ (rabbit polyclonal antibodies, ab133273, Abcam) and anti-Alfa smooth muscle actin ( $\alpha$-SMA) antibody (1:500 dilution $^{[22]}$ ) (mouse monoclonal antibody, clone 1A4, ab7817, Abcam), in PBS overnight at $4^{\circ} \mathrm{C}$. Thereafter, it was washed in PBS buffer, and co-incubated with biotinylated secondary antibody (Dako North America, Inc., CA, USA) for one hour at room temperature. Streptavidin peroxidase was added for 10 minutes and rinsed three times in PBS. The immunoreactivity was visualized using 3, 3'diaminobenzidine (DAB)-hydrogen peroxide as a chromogen. Finally, the sections were counterstained with Mayer's haematoxylin. The negative control sections were processed without addition of the primary antibodies ${ }^{[23]}$. For positive controls, the human prostate adenocarcinoma tissue was used for AR and Human breast ductal carcinoma tissue was used for $\alpha$-SMA ${ }^{[24,25]}$. For Bcl2, human colon carcinoma tissue was used as a positive control according to the product data sheet.

\section{Morphometric assessment and statistical analysis}

For morphometric study, Image analysis system (Leica Q 500 MC program) at Central Research Lab, Tanta Faculty of Medicine was used to determine the following parameters "in ten different fields from each specimen":

1. The height of the prostatic epithelium $(\mu \mathrm{m})$ in H\&E stained sections (X400). 
2. The area percentage of collagen fibers (\%) in Mallory trichrome stained slides (X200).

3. The color intensity of the positive immunoreaction for Bcl-2 (X1000), $\alpha$-SMA (X400), AR (X1000).

For analysis of the morphometric data, one-way analysis of variance (ANOVA) followed by Tukey's procedure was performed for comparison between all groups by using statistical package for social sciences statistical analysis software (version 11.5; SPSS Inc., Chicago, Illinois, USA). Mean values \pm standard deviation were calculated. Probability values $P<0.05$ was considered as significant.

\section{RESULTS}

No deaths were reported in the present work.

\section{I- Histological results}

\section{$H \& E$ stain}

Specimens obtained from all control subgroups (Group I) showed the same normal histological structure of rat ventral prostate. Prostatic acini of variable sizes and shapes appeared with thin fibromuscular stroma between them. The glandular epithelium of the acini was simple cuboidal and/or columnar having basal rounded or oval nuclei. Some acini exhibited epithelial folding into their lumen which was filled with homogenous acidophilic secretion (Figures1 and 2).

Examination of the prostate specimens of diabetic group (Subgroup IIA) revealed some alterations in the histological structure of the acini and stroma. There was apparent reduction in size of the acini and lumen compared to control group. The acini were separated by wide spaces containing stromal elements. The glandular epithelium was low (cuboidal or flat) with less epithelial folds (Figure 3). Some epithelial cells showed vacuolated cytoplasm and small deeply stained pyknotic nuclei (Figure 4). Scanty lightly stained prostatic secretion was observed in the lumen of other acini. Thickened stroma with cellular infiltration and dilated congested blood vessels was noticed (Figure 5).

Concerning the diabetic-flaxseed group (Subgroup IIB), administration of the flaxseed extract to diabetic rats partially preserved most of the epithelial and stromal structures. The glandular epithelium was mostly columnar and appeared taller than the diabetic group. In addition, the stromal spaces between the prostatic acini became narrower than that of the diabetic group (Figure 6).

\section{Mallory's trichrome stain}

Mallory's trichrome-stained sections of the control group showed scanty collagen fibers in the stroma between the prostatic acini (Figure 7). The diabetic group showed abundant collagen fibers deposition between the acini (Figure 8), whereas sections from the diabetic-flaxseed group revealed minimal amount of collagen fibers between the prostatic acini (Figure 9).

\section{II- Immunohistochemical results}

Bcl2 antigen immunostaining: Bcl2-immunostained prostate sections of the control group (Group I) showed strong positive cytoplasmic immunoreaction for $\mathrm{Bcl} 2$ in the acinar cells (Figure 10). Diabetic group (Subgroup IIA) showed that numerous acinar cells expressed weak positive cytoplasmic immunoreaction for Bcl2 (Figure 11), while the diabetic-flaxseed group (Subgroup IIB) expressed moderate positive cytoplasmic immunoreaction for $\mathrm{Bcl} 2$ in some acinar cells (Figure 12).

$\alpha$-SMA immunstaining: $\alpha$-SMA immunostained prostate sections from the control group (Group I)revealed weak positive cytoplasmic immunoreaction in the smooth muscle cells around the prostatic acini (Figure 13). In the diabetic group (Subgroup IIA), a strong positive cytoplasmic immunoreaction for $\alpha$-SMA was noticed in the smooth muscle cells around the proatatic acini (Figure 14) while the diabetic-flaxseed group (Subgroup IIB), a moderate positive cytoplasmic immunoreaction appeared (Figure 15).

Androgen receptor immunostaining: ARimmunostained prostate sections of the control group (Group I) showed a strong positive nuclear reaction in the acinar and stromal cells (Figure 16). In the diabetic group (Subgroup IIA), a weak positive nuclear reaction for AR was observed in many acinar and stromal cells (Figure 17), whereas in the diabetic-flaxseed group (Subgroup IIB) a moderate positive nuclear reaction for AR was detected in some acinar and stromal cells (Figure 18).

\section{III-Morphometric and statistical results (Table 1)}

The mean height of the prostatic epithelium in the diabetic group (Subgroup IIA) was significantly decreased compared to the control, while the diabetic-flaxseed group (Subgroup IIB) showed a non-significant decrease compared to the control.

The mean area percentage of collagen fiber content in the diabetic group (Subgroup IIA) showed a significant increase compared to the control group, while the diabeticflaxseed group (Subgroup IIB) showed a non-significant increase compared to control group.

The mean color intensity of Bcl2-positive immunoreaction in the diabetic group (Subgroup IIA) showed a significant decrease compared with the control group, whereas the diabetic-flaxseed group (Subgroup IIB) showed a non-significant decrease compared with the control.

The mean color intensity of $\alpha$-SMA positive immunoreaction in the diabetic group (Subgroup IIA) showed a significant increase compared to the control group, while the diabetic-flaxseed group (Subgroup IIB) showed a non-significant increase compared to the control.

The mean color intensity of AR-positive immunoexpression in the diabetic group (Subgroup IIA) 
showed a significant decrease compared with the control group, whereas the diabetic-flaxseed group (Subgroup IIB) showed a non-significant decrease compared with the control.

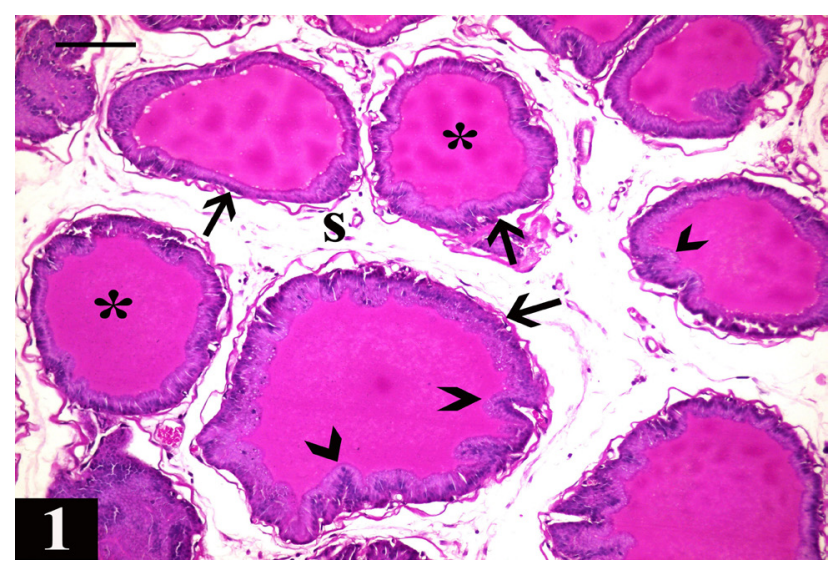

Fig. 1: A photomicrograph of a section in the ventral prostate of an adult albino rat from the control group showing prostatic acini (arrow) of variable sizes and shapes with thin fibromuscular stroma (S) in between. Notice the epithelial folds (arrow head) into the acinar lumen which is filled with homogenous acidophilic secretion (*). (H\&E, X200; Scale bar $=100 \mu \mathrm{m})$

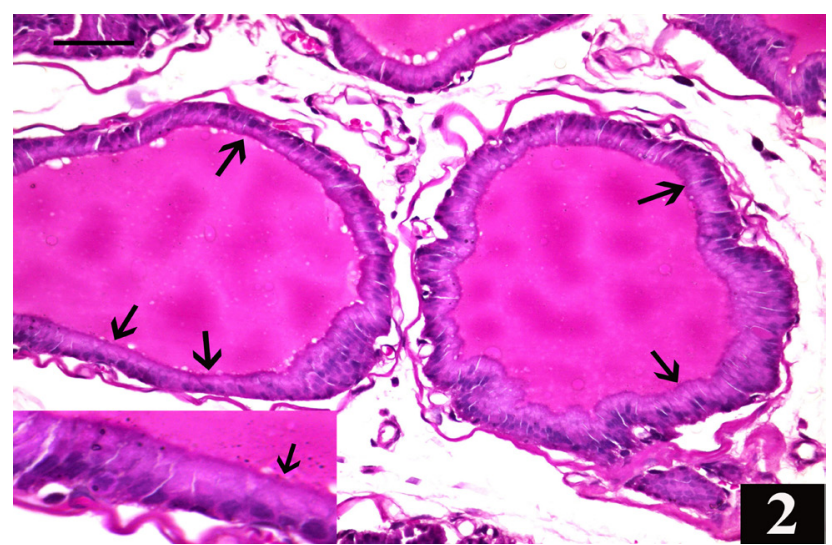

Fig. 2: A higher magnification of the previous prostatic acini lined with either simple cuboidal and/or columnar epithelium (arrow) having basal rounded or oval nuclei. (H\&E, X400; Inset, X1000; Scale bar $=50 \mu \mathrm{m})$

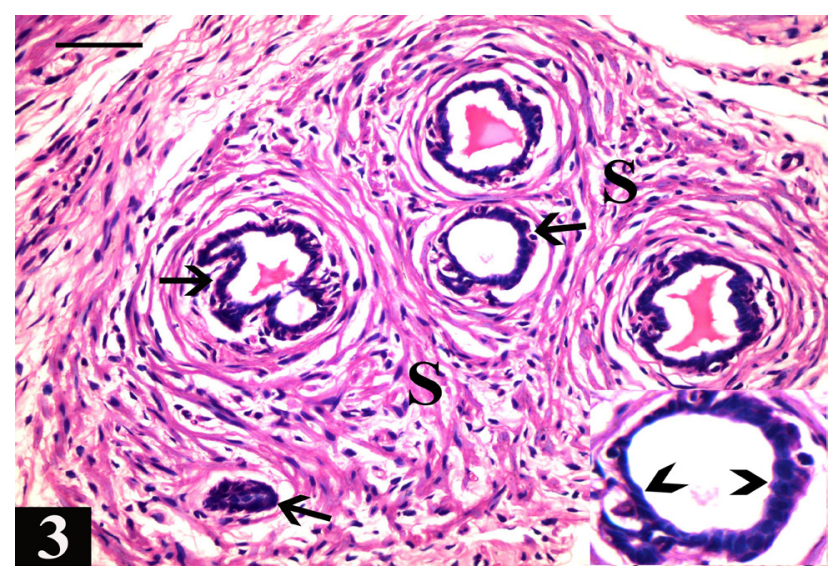

Fig. 3: A photomicrograph of a section in the ventral prostate of an adult albino rat from the diabetic group (Subgroup IIA) showing apparent marked decrease in size and lumen of some acini (arrow) with thick condensed stroma (S) in between. The inset shows low cuboidal or flat epithelium with minimal epithelial folds (arrow head). (H\&E, X400; Inset, X1000; Scale bar $=50 \mu \mathrm{m}$ )

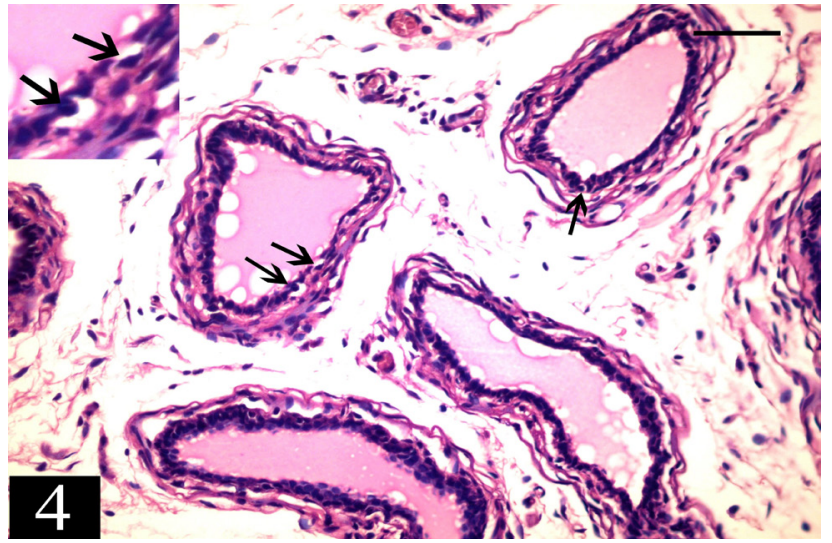

Fig. 4: A photomicrograph of a section in the ventral prostate of an adult albino rat from the diabetic group (Subgroup IIA) showing some epithelial cells with vacuolated cytoplasm and small deeply stained pyknotic nuclei

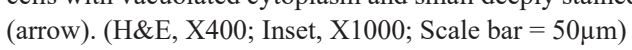

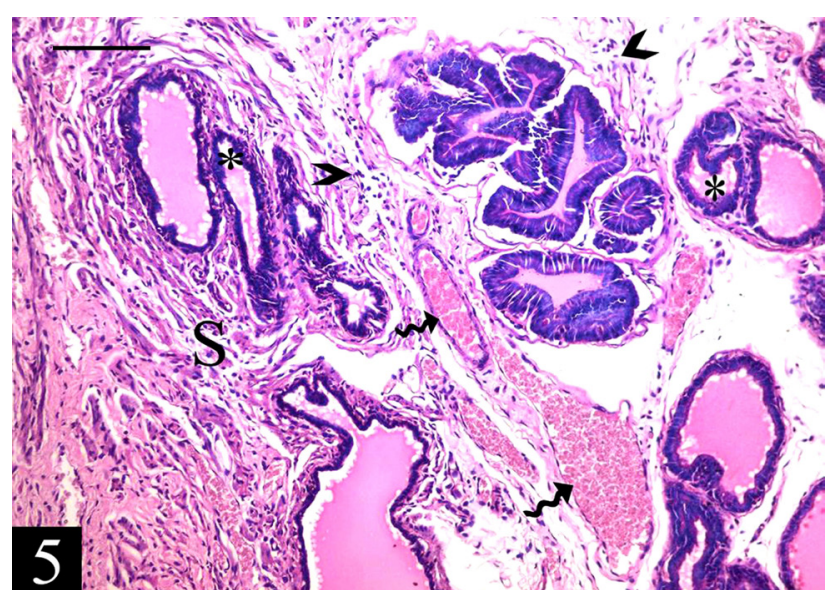

Fig. 5: A photomicrograph of a section in the ventral prostate of an adult albino rat from the diabetic group (Subgroup IIA) showing increased stroma (S) with abnormal cellular infiltration [arrow head] and dilated congested blood vessels (wavy arrow). Notice the scanty lightly stained prostatic secretion in the lumen of some acini (*). (H\&E, X200; Scale bar $=100 \mu \mathrm{m})$

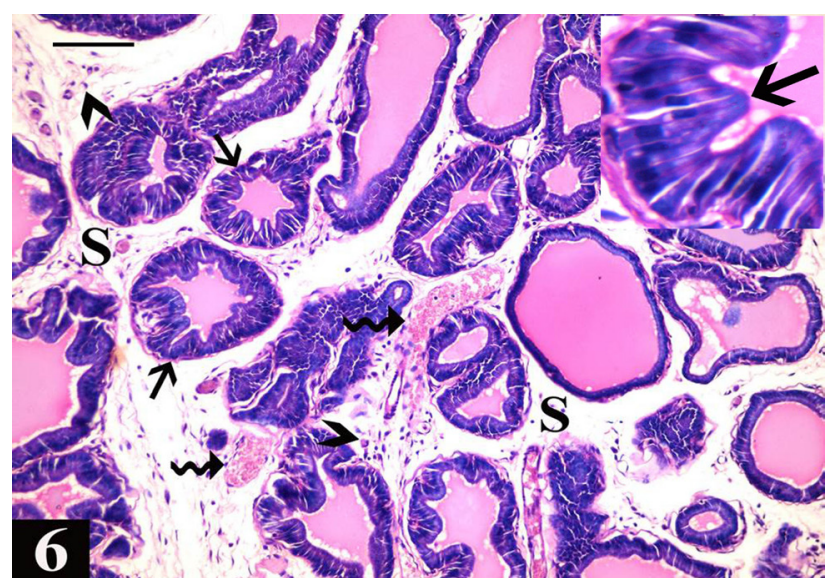

Fig. 6: A photomicrograph of a section in the ventral prostate of an adult albino rat from the diabetic-flaxseed group (Subgroup IIB) showing prostatic acini lined mostly by columnar epithelium with numerous epithelial folds (arrow). Notice apparently narrow stromal spaces (S) between the acini with few infiltrating cells (arrow head) and mild dilated congested blood vessels (wavy arrow). (H\&E, X200; Inset, X1000; Scale bar $=100 \mu \mathrm{m}$ ) 


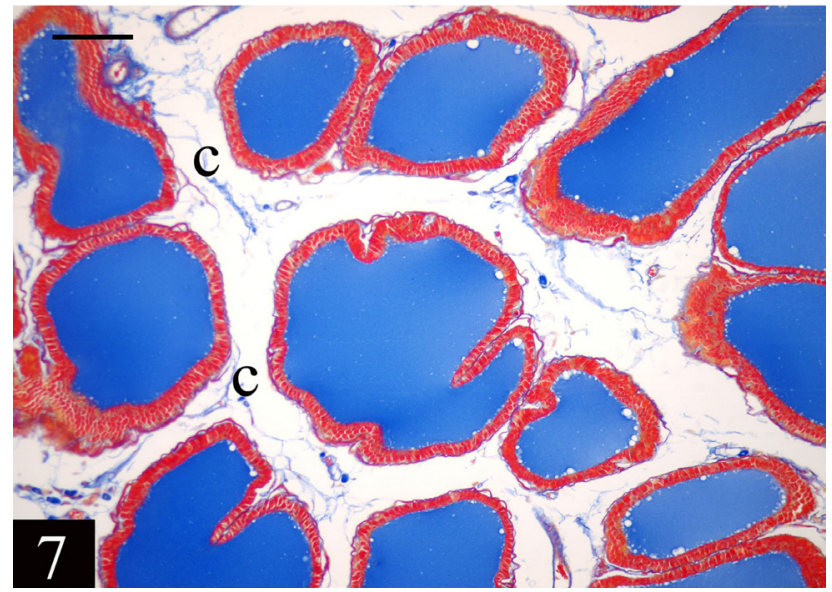

Fig. 7: A photomicrograph of a section in the ventral prostate of an adult albino rat from the control group showing scanty collagen fibers (C) in the stroma between the prostatic acini. (Mallory's trichrome, X200; Scale bar $=100 \mu \mathrm{m})$

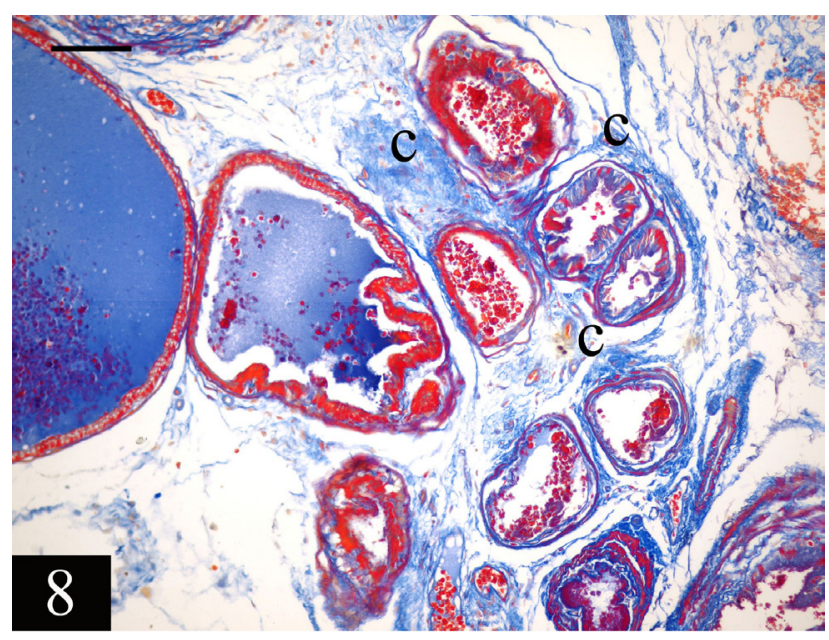

Fig. 8: A photomicrograph of a section in the ventral prostate of an adult albino rat from the diabetic group (Subgroup IIA) showing abundant collagen fibers $(\mathrm{C})$ deposition in the stroma between the prostatic acini. (Mallory's trichrome, X200; Scale bar $=100 \mu \mathrm{m}$ )

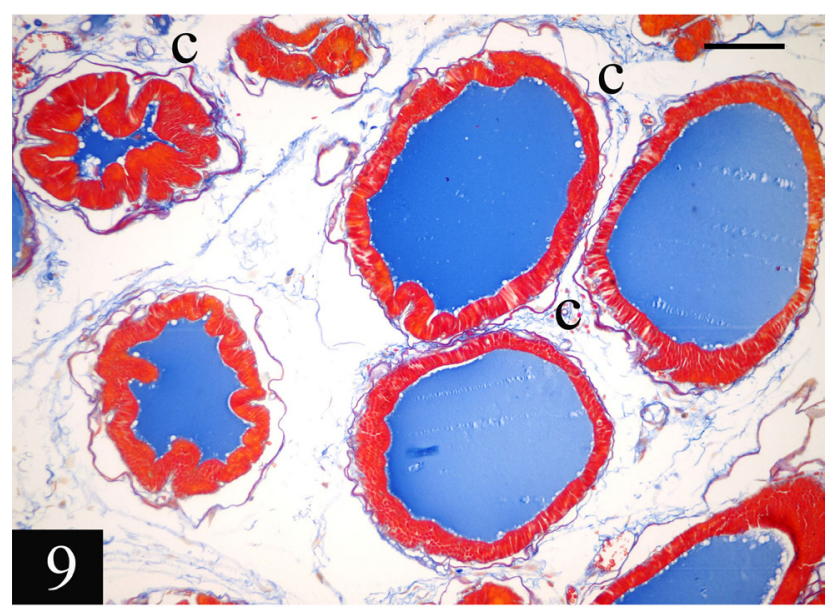

Fig. 9: A photomicrograph of a section in the ventral prostate of an adult albino rat from the diabetic-flaxseed group (Subgroup IIB) showing minimal collagen fibers $(C)$ in the stroma between the prostatic acini. (Mallory's trichrome, X200; Scale bar $=100 \mu \mathrm{m}$ )

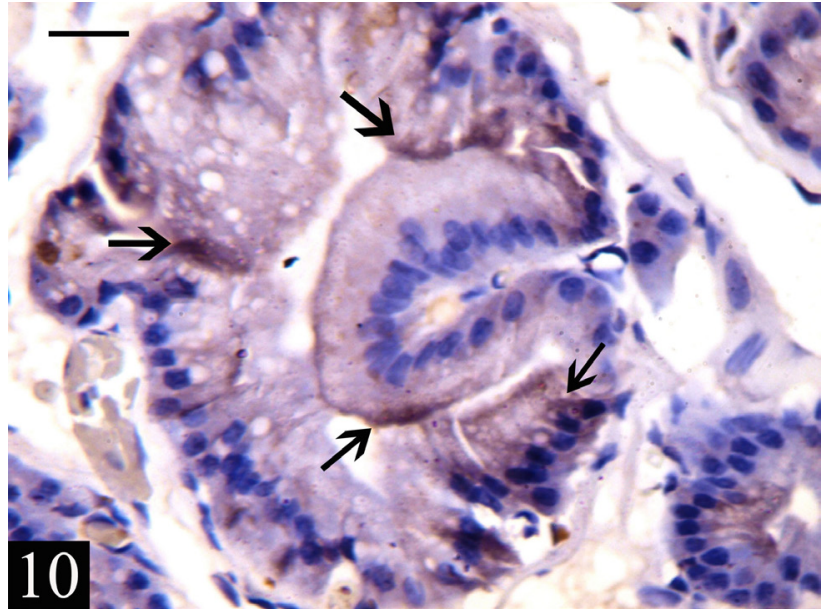

Fig. 10: A photomicrograph of a section in the ventral prostate of an adult albino rat from the control group showing strong positive cytoplasmic immunoreaction for Bcl2 in the acinar cells (arrow). (Bcl2 immunostaining, X 1000; Scale bar $=25 \mu \mathrm{m}$ )

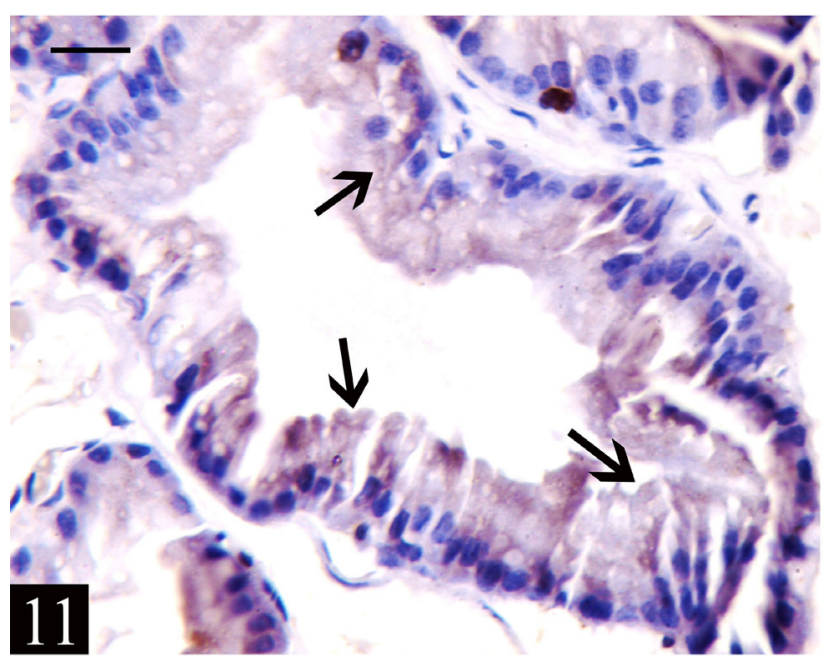

Fig. 11: A photomicrograph of a section in the ventral prostate of an adult albino rat from the diabetic group (Subgroup IIA) showing weak positive cytoplasmic reaction for Bcl2 in many acinar cells (arrow). (Bcl2 immunostaining, $X 1000$; Scale bar $=25 \mu \mathrm{m}$ )

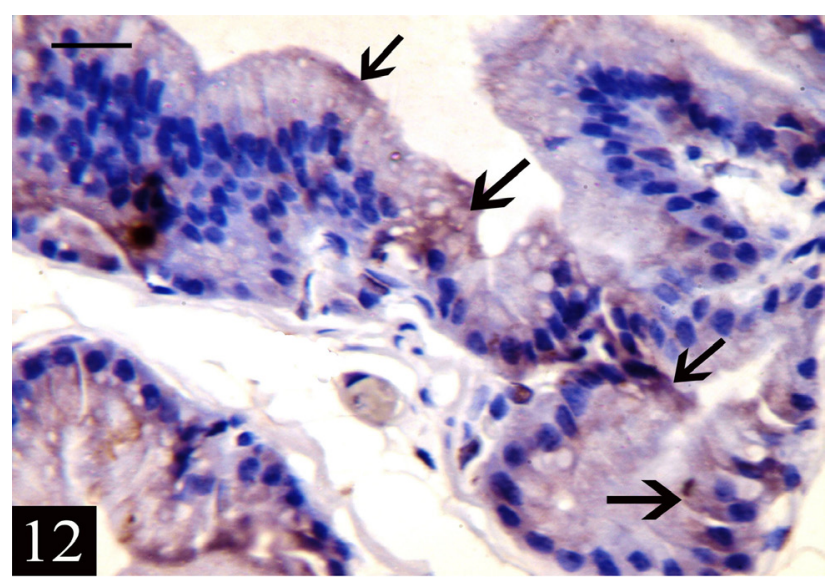

Fig. 12: A photomicrograph of a section in the ventral prostate of an adult albino rat from the diabetic-flaxseed group (Subgroup IIB) showing moderate positive cytoplasmic reaction for $\mathrm{Bcl} 2$ in some acinar cells (arrow). (Bcl2 immunostaining, X 1000; Scale bar $=25 \mu \mathrm{m}$ ) 


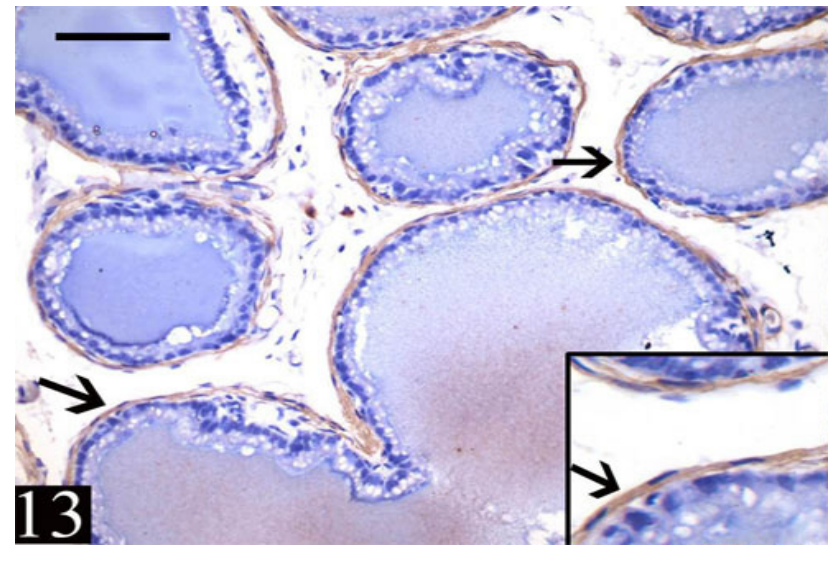

Fig. 13: A photomicrograph of a section in the ventral prostate of an adult albino rat from the control group showing weak positive cytoplasmic immunoreaction for $\alpha$-SMA in the smooth muscle cells around the prostatic acini (arrow). ( $\alpha$-SMA immunostaining, X 400; inset, X 1000; Scale bar $=25 \mu \mathrm{m})$

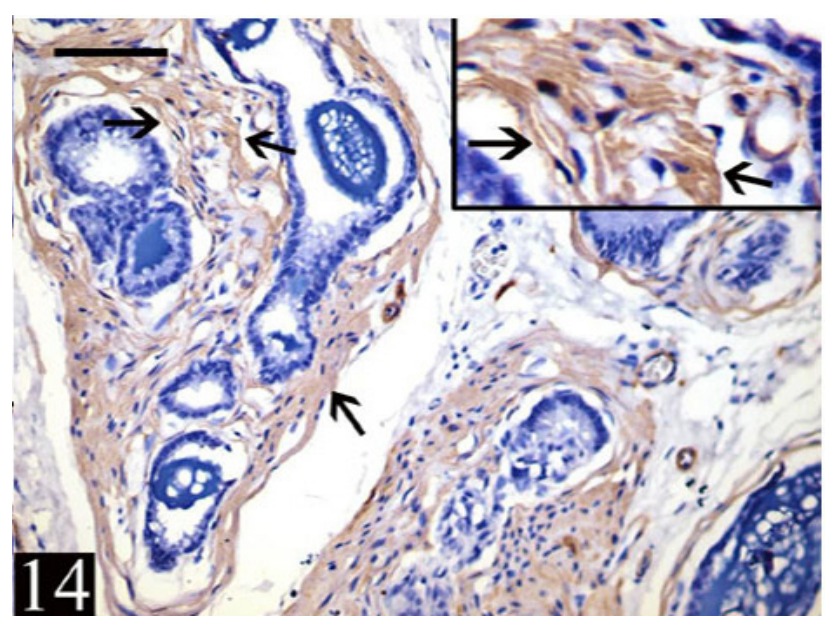

Fig. 14: A photomicrograph of a section in the ventral prostate of an adult albino rat from the diabetic group (Subgroup IIA) showing strong positive cytoplasmic reaction for $\alpha$-SMA in the smooth muscle cells around the prostatic acini (arrow). ( $\alpha$-SMA immunostaining, X 400; inset, X 1000; Scale bar $=25 \mu \mathrm{m})$

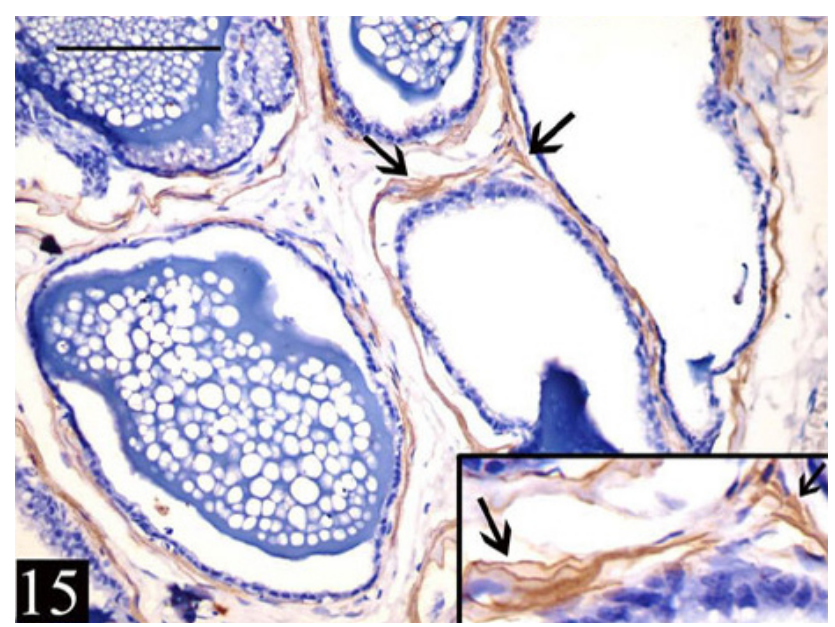

Fig. 15: A photomicrograph of a section in the ventral prostate of an adult albino rat from the diabetic-flaxseed group (Subgroup IIB) showing moderate positive cytoplasmic reaction for $\alpha$-SMA in the smooth muscle cells around the prostatic acini (arrow). ( $\alpha$-SMA immunostaining, X 400; inset, X 1000; Scale bar $=25 \mu \mathrm{m}$ )

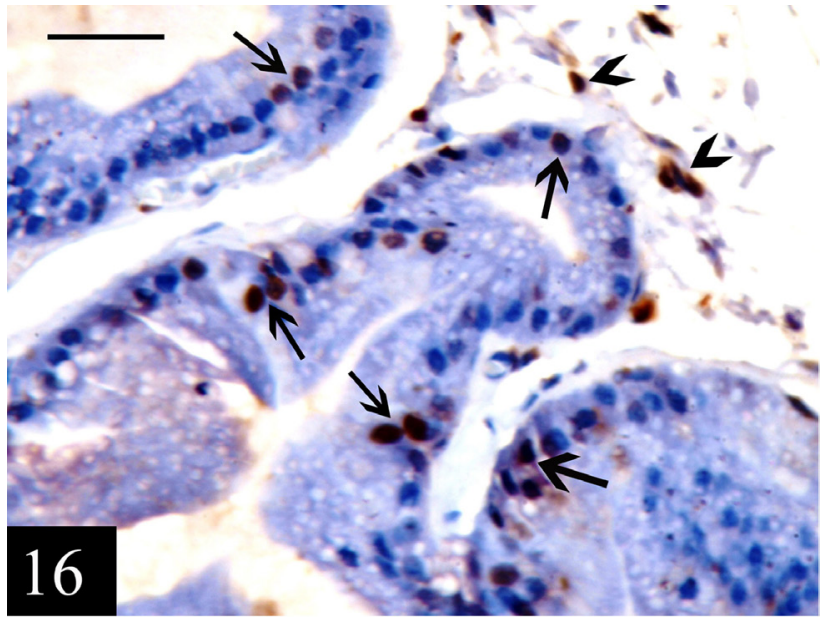

Fig. 16: A photomicrograph of a section in the ventral prostate of an adult albino rat from the control group showing strong positive nuclear immunoreaction for AR in the acinar (arrow) and stromal (arrow head) cells. (AR immunostaining, X 1000; Scale bar $=25 \mu \mathrm{m})$

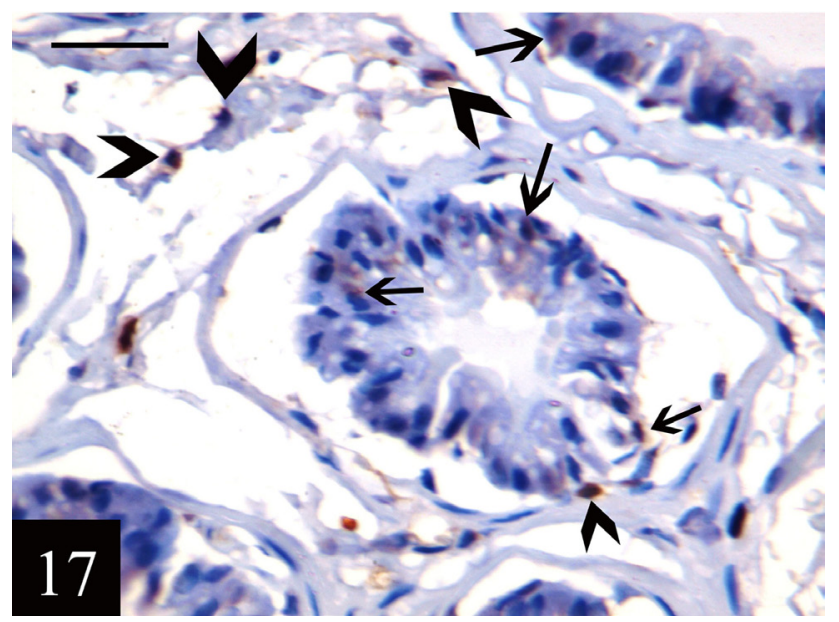

Fig. 17: A photomicrograph of a section in the ventral prostate of an adult albino rat from the diabetic group (Subgroup IIA) showing weak positive nuclear reaction for AR in many acinar (arrow) and stromal (arrow head) cells. (AR immunostaining, X 1000; Scale bar $=25 \mu \mathrm{m}$ )

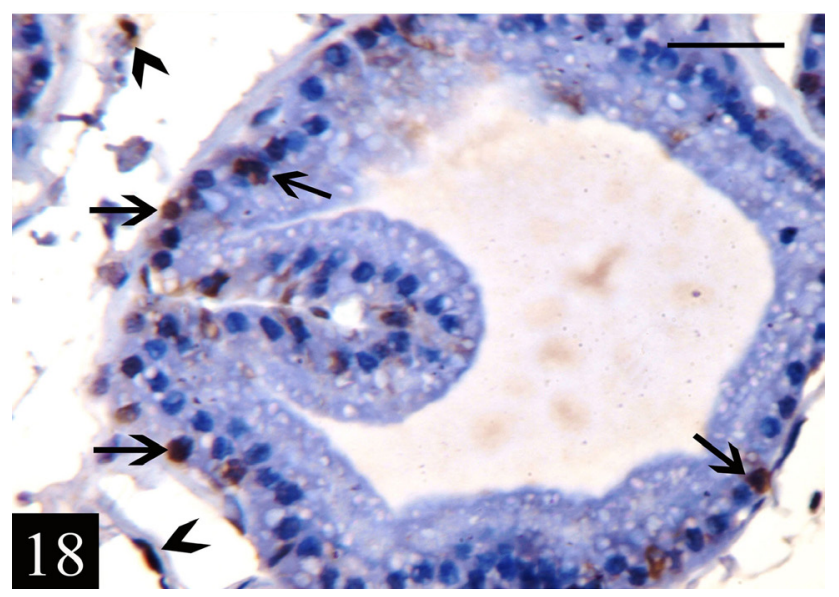

Fig. 18: A photomicrograph of a section in the ventral prostate of an adult albino rat from the diabetic-flaxseed group (Subgroup IIB) showing moderate positive nuclear reaction for AR in some acinar (arrow) and stromal (arrow head) cells. (AR immunostaining, X 1000; Scale bar = $25 \mu \mathrm{m})$ 
Table 1: Summarizes the epithelial height, the area percentage of collagen fibers and the color intensity of Bcl2, $\alpha$-SMA and $\mathrm{AR}$ immunoreaction [Mean \pm standard deviation] in different rat groups.

\begin{tabular}{lccc}
\hline Garameters & Group I & Group IIA & Group IIB \\
\hline $\begin{array}{l}\text { Epithelial } \\
\text { height }(\mu \mathrm{m})\end{array}$ & $13.118 \pm 0.696$ & $7.558 \pm 0.647^{*}$ & $12.406 \pm 0.813$ \\
\hline $\begin{array}{l}\text { Area percentage of } \\
\text { collagen fibers (\%) }\end{array}$ & $8.295 \pm 0.580$ & $15.276 \pm 0.939^{*}$ & $8.777 \pm 0.459$ \\
\hline $\begin{array}{l}\text { Color intensity } \\
\text { of Bcl2 }\end{array}$ & $66.219 \pm 0.897$ & $50.371 \pm 1.167^{*}$ & $65.497 \pm 0.612$ \\
\hline $\begin{array}{l}\text { Color intensity } \\
\text { of } \alpha-S M A\end{array}$ & $18.464 \pm 0.963$ & $25.645 \pm 0.948^{*}$ & $19.324 \pm 0.863$ \\
\hline $\begin{array}{l}\text { Color intensity } \\
\text { of AR }\end{array}$ & $26.191 \pm 0.907$ & $17.821 \pm 0.883^{*}$ & $25.475 \pm 0.549$ \\
\hline
\end{tabular}

$* P<0.05$ is significant versus control (Group I)

\section{DISCUSSION}

Fertility dysfunction is considered a major diabetic complication in males due to the detrimental effects of diabetes on the reproductive system. These complications are generally not preventable; therefore clinicians must be aware of the potential fertility complications caused by diabetes mellitus ${ }^{[26]}$. Many clinical studies have reported the health benefits of flaxseed and its effective role in controlling the blood glucose level in diabetic patients ${ }^{[13]}$. Accordingly, this work aimed to study the effect of streptozotocin-induced diabetes on the ventral prostate gland in adult albino rats and to evaluate the potential role of flaxseed extract in ameliorating the diabetic effect on the prostate employing different histological and immunohistochemical methods.

After reviewing the results of this study, it could be concluded that streptozotocin-induced diabetes altered the histological structure of the ventral prostate gland in rats. These were in the form of atrophic changes and apoptosis in the glandular epithelium which showed a significant reduction in the mean epithelial height and $\mathrm{Bcl} 2$ immunoexpression (anti-apoptotic protein). In addition, there was marked thickening of the fibromuscular stroma which showed a significant increase in collagen area percentage and $\alpha$-SMA immunoexpression (a specific marker for smooth muscle cells). Moreover, there was a significant reduction in AR immunoexpression in both epithelial and stromal cells of diabetic rats. Administration of flaxseed extract to diabetic rats protected the prostate tissue and partially prevented most of the epithelial and stromal changes appearing more or less as control group.

These results coincided with previous studies indicating that Streptozotocin-induced DM suppressed the reproductive activity due to hyperglycaemia-induced oxidative stress and structural alterations in the teste ${ }^{[3,5,27]}$. Moreover, other study reported that the prostate structural changes observed in diabetic animals were identical to those observed in castrated animals ${ }^{[28]}$.
The prostate epithelial changes were attributed to lack of the anabolic activity of insulin as well as depletion of testosterone which have an important role in epithelial cell proliferation and normal secretory function leading to severe epithelial atrophy in diabetic rats ${ }^{[4]}$. This was evident in this study by the significant decrease in the height of the glandular epithelium.

It was reported that DM-associated hyperglycemia induces oxidative stress through free radical over load or defective endogenous antioxidant mechanisms. In addition, DM causes reduced serum testosterone level due to its damaging effects on testicular and epididymal structure as well as low luteinizing hormone (LH) level and suppression of lydig cell activity. So, hyperglycemiainduced oxidative stress and reduced testosterone level in diabetic rats may responsible for prostate damage ${ }^{[5]}$.

This study showed a statistically significant increase in the collagen area percentage and $\alpha$-SMA immunoexpression denoting stromal tissue hypertrophy. This finding coincided with other studies which reported marked thickening of the extracellular matrix of the prostate gland with increased collagen deposition and hypertrophied smooth muscle cells in diabetic and castrated rats. These stromal changes were attributed to androgen depletion and were explained by being an attempt to preserve the integrity of the glandular epithelium and the secretory process ${ }^{[9,29,30]}$. In addition, this increase in the stromal elements of diabetic prostate would induce a reactive stromal microenvironment that may lead to proliferation, cell migration and pathological processes. So, it could be concluded that diabetes induced effective remodeling of the stroma of the prostate gland leading to increase in collagen fibers and smooth muscle cells hypertrophy ${ }^{[4,31]}$.

The results of this research revealed also a statistically significant decrease in the immunoexpression of $\mathrm{Bcl} 2$ indicating increased apoptosis in the glandular epithelium. $\mathrm{Bcl} 2$ is a protein that belongs to $\mathrm{Bcl}-2$ family and plays an anti-apoptotic role. Overexpression of Bcl-2 enhances cell survival by suppressing apoptosis. In cells subjected to apoptosis-inducing stimuli as diabetes, $\mathrm{Bcl} 2$ expression is significantly reduced and is associated with increased level of pro-apoptotic protein such as Bax. The increased Bax/ $\mathrm{Bcl} 2$ ratio leads to cytochrome-c release from mitochondria triggering apoptosis ${ }^{[32]}$. This was in agreement with the findings of other researchers ${ }^{[5]}$. Many studies reported that DM stimulates apoptosis and reduces cell proliferation in various organs. This was discussed to be directly related to low testosterone level and oxidative stress induced DNA damage. Testosterone has the ability to up regulate the anti-apoptotic gene expression for $\mathrm{Bcl} 2^{[33,34,35]}$. In addition, there was a significant decrease in AR immunoexpression which was related mainly to testosterone depletion in diabetic condition ${ }^{[36]}$. It was reported that the expression of AR mRNA decreases in epididymis, testis and prostate of diabetic rats that weaken the biological effects of AR. So, this might be responsible for prostate dysfunction in $\mathrm{DM}^{[37]}$. 
In the current study, flaxseed extract was introduced to evaluate its probable role in alleviating the diabetic effect on prostate. Flaxseed extract exerted a protective effect on prostate tissue that was evident in the different histological and immunohistochemical findings. The parenchymal and stromal structures were partially preserved. It was proved that flaxseed possesses hypoglycemic effect which was attributed mainly to its anti-oxidative activity. In addition, it contains dietary fibers that delay the glucose absorption in the digestive system. It activates the extra cellular signal regulated kinase pathway to control the secretion of a glucagons-like peptide-1, thereby enhancing the insulin secretion. Moreover, it decreases insulin resistance and improves insulin action by increasing glucose transport ${ }^{[13]}$. Flaxseed is a rich source for lignans that have antidiabetic action through lowering C-reactive protein concentration which is linked to insulin resistance. So, it enhances peripheral insulin sensitivity aiding in prevention and control of diabetes mellitus type I and type $\mathrm{II}^{[10,38]}$. Therefore, This could in part explain the ameliorating anti-diabetic effect exerted by flaxseed extract on prostate during the course of the present study.

Flaxseed reduces the oxidative stress and DNA damage in different tissues of rats ${ }^{[11]}$. The most abundant vitamin in flaxseed is vitamin $\mathrm{E}$ which protects cell components from the damaging effects of free radicals ${ }^{[39,40]}$. It increases anti-oxidant enzymes in addition to its free radicals scavenging effect. Therefore, the beneficial effects of flaxseed in controlling diabetes were attributed not only to its hypoglycemic effect but also to its anti-oxidant activity ${ }^{[11,42,43]}$.

Additionally, Flaxseed controls the inflammatory biomarker levels and reduces the cellular infiltration and fibrosis ${ }^{[13,44]}$. It reduces the production of the inflammatory cytokines as IL-1, IL-6, TNF and CRP through inhibition of NF-Kb (nuclear factor kappa-light-chain-enhancer of activated B cells). This anti-inflammatory action was attributed to omega- 3 fatty acids which are one of the flaxseed constituents. Omega- 3 fatty acids regulate the expression of adhesion molecules as VCAM-1 that helps in leukocyte-endothelial interaction ${ }^{[42,45,46]}$. Previous study on prostate gland showed that flaxseed modulates the enzymes involved in hormone metabolism that can improve prostate metabolism $^{[47]}$.

Moreover, it was reported that $10 \%$ dietary flaxseed increases serum testosterone level as well as serum LH level and improves sperm count ${ }^{[48]}$. This was in line with the increased AR immunoexpression as well as the decreased collagen area percentage and $\alpha$-SMA immunoexpression in diabetic flaxseed group due to improved serum androgen level.

Flaxseed exerted also anti-apoptotic effect on prostate which was attributed to its active constituent $\alpha$-linolenic acid. It disrupts intrinsic and extrinsic cell death pathways triggered by sustained inflammatory cytokine stimulation. It prevents cytochrome-c release and inhibits the depolarization of the mitochondrial outer membrane caused by cytokines. The mechanism by which flaxseed interfered with cytochrome-c release is by regulating the $\mathrm{Bcl}-2$ family proteins and $\mathrm{Bax} / \mathrm{Bcl} 2$ ratio blocking the apoptotic cascade ${ }^{[49,50]}$.

It was reported that flaxseed promotes tissue regeneration in various organs as pancreatic islets and bone ${ }^{[51,52]}$. In addition, the linolenic acid in flaxseed promotes the cell viability and proliferation activity of stem cells ${ }^{[53]}$. The prostate stem/progenitor cells were identified and characterized. It has been hypothesized that these cells are found in the basal cell layer of the prostatic acini and they are independent of androgen for their survival. The regeneration of the parenchymal structures is dependent on proliferation of the basal cells of the acini ${ }^{[54]}$. So, flaxseed promoted the proliferative activity of the prostate stem/ progenitor cells to preserve the parenchymal structure of prostate in diabetic rats.

In conclusion, this study showed that streptozotocininduced diabetes altered the histological structure of the ventral prostate gland in rats. Flaxseed extract exerted a potent protective effect on prostate gland of diabetic rats through its anti-diabetic (hypoglycemic), anti-oxidant, anti-inflammatory and anti-apoptotic activities. Therefore, flaxseed may be a useful therapeutic agent for diabetic patients to minimize the prostate complications.

\section{CONFLICTS OF INTEREST}

There are no conflicts of interest.

\section{REFERENCES}

1. Lotfy M, Adeghate J, Kalasz H, Singh J, Adeghate E [2017]: Chronic Complications of Diabetes Mellitus: A Mini Review. Current Diabetes Reviews, 13: 3-10.

2. Soudamani S, Yuvaraj S, Malini T, Balasubramanian K [2005]: Experimental Diabetes Has Adverse Effects on the Differentiation of Ventral Prostate During Sexual Maturation of Rats. THE ANATOMICAL RECORD PART A 287A:12811289.

3. Sönmez MF, Karabulut D, Kilic E, Akalin H, Sakalar C, Gunduz Y, Kara A, Dundar M [2015]: The effects of streptozotocin-induced diabetes on ghrelin expression in rat testis: biochemical and immunohistochemical study. FOLIA HISTOCHEMICA ET CYTOBIOLOGICA, 53 [1]: 26-34.

4. Eid BG, Mosli H, Hasan A, El-Bassossy HM [2017]: Ginger Ingredients Alleviate Diabetic Prostatic Complications: Effect on Oxidative Stress and Fibrosis. Evidence-Based Complementary and Alternative Medicine Volume 2017, Article ID 6090269:1- 12. 
5. Popoola B, Ashefor O, Akanni O, Adaramoye O [2017]: Biochemical, Hormonal and Histological Changes in Prostate of Wistar Rats Following Long Term Streptozotocin-induced Diabetes Mellitus. Niger. J. Physiol. Sci. 32: 75-84.

6. Elabbady A, Hashad MM, Kotb AF, Ghanem AE [2016]: Studying the effect of type 2 diabetes mellitus on prostate-related parameters: A prospective single institutional study. Prostate Int, 4:156-159.

7. Barnard RJ, Obayashi NK, Aronson WJ [2008]: Effect of diet and exercise intervention on the growth of prostate epithelial cells. Prostate Cancer Prostatic Dis, 11:362-6.

8. Sluczanowska-Glabowska S, Laszczyñska M, Wylot M, Glabowski W, Piasecka M, Gacarzewicz D [2010]: Morphological and immunohistochemical compare of three rat prostate lobes [lateral, dorsal and ventral] in experimental hyperprolactinemia. FOLIA HISTOCHEMICA ET CYTOBIOLOGICA, 48[3]: 447-454.

9. Antonioli E, Della-Colleta HHM, Carvalho HF [2004]: Smooth Muscle Cell Behavior in the Ventral Prostate of Castrated Rats. Journal of Andrology, 25 [1]: 50-56.

10. Imran M, Ahmad N, Anjum FM, Khan MK, Mushtaq Z, Nadeem M, Hussain S [2015]: Potential protective properties of flax lignan secoisolariciresinol diglucoside. Nutrition Journal 14:71.

11. Mishra S and Verma P [2013]: Flaxseed- Bioactive compounds and health significance. IOSR Journal of Humanities and Social Science [IOSR-JHSS] 17 [3]: 46-50.

12. Alachaher FZ, Dali S, Dida N, Krouf D [2018]: Comparison of phytochemical and antioxidant properties of extracts from flaxseed [Linum usitatissimum] using different solvents. International Food Research Journal [IFRJ] 25[1]: $75-82$.

13. Tharwat S, Shaheen D, El-Megeid AA, Salam R, Rashed L, et al. [2017]: Effectiveness of Adding Flaxseed to Type 2 Diabetic Patient's Regimen. Endocrinol Metab Syndr 6 [3]: 267.

14. Ahmad N, Rahman ZU, Akhtar N, Ali S [2012]: Effects of aqueous methanolic extract of Flax seeds [Linum usitatissimum] on serum estradiol, progesterone, kidney and liver functions and some serum biochemical metabolites in immature female rats. Pak Vet J, 32[2]: 211-215.

15. Al-Ania IM, Abireda AN, Mustafab BE, Wahaba ENA, Azzubaidi MS [2017]: Effect of Flaxseed Extract on the Liver Histological Structure in
Streptozotocin Induced Diabetic Rats. International Medical Journal Malaysia 16 [1]: 91-98.

16. Arcolino O, Ribeiro L, Gobbo G, Taboga R, Goes M [2010]: Proliferation and apoptotic rates and increased frequency of p63-positive cells in the prostate acinar epithelium of alloxan-induced diabetic rats. Int J Exp Pathol 91:144-54.

17. Gaertner DJ, Hallman TM, Hankenson FC, Batcherder MA [2008]: Anesthesia and analgesia for laboratory rodents. Anesthesia and analgesia in laboratory animals. 2 nd edition. Academic press, San Diego, CA. Boston. 239 -240.

18. Bancroft JD and Gamble M [2008]. Theory and practice of histological techniques. 6th ed. Philadelphia: Churchill Livingstone: Elsevier Health Science; 126-127.

19. Culling CFA, Allison RT and Barr WT [1985]: Cellular pathology technique, 4thed., Mid-County Press, London, pp. 164-180.

20. Liu S, LI X, LI Q, LIU H, SHI Y, ZHUO H, LI C, ZHU H [2018]: Silencing Livin improved the sensitivity of colon cancer cells to 5-fluorouracil by regulating crosstalk between apoptosis and autophagy. Oncol Lett 15:7707-7715.

21. Azeem W, Hellem MR, Olsen JR, Hua Y, Marvyin $\mathrm{K}, \mathrm{Qu} \mathrm{Y}$, et al. [2017]: An androgen response element driven reporter assay for the detection of androgen receptor activity in prostate cells. PLoS ONE 12[6]: e0177861.

22. Essawy TA and Hakam HM [2009]: The expression of alpha-smooth muscle actin $[\alpha$-SMA $]$ in posterior lingual glands in normal and diabetic rats. C.D.J. 25 [2]: 149-157.

23. Ramos-Vara JA, Kiupel M, Baszler T, Bliven L, Brodersen B, Chelack B, et al [2008]. Suggested guidelines for immunohistochemical techniques in veterinary diagnostic laboratories. J Vet Diagn Invest 20: 393-413.

24. Valkenburg KC, De Marzo AM, Williams BO [2017]: Deletion of tumor suppressors adenomatous polyposis coli and Smad4 in murine luminal epithelial cells causes invasive prostate cancer and loss of androgen receptor expression. Oncotarget 8[46]: 80265-80277.

25. Chang J, Lucas MC, Leonte LE, Garcia-Montolio M, Singh LB, Findlay AD, et.al. [2017]: Preclinical evaluation of small molecule LOXL2 inhibitors in breast cancer. Oncotarget 8 [16]: 26066-26078.

26. Dkhil MA, Zrieq R, Al-Quraishy S, Abdel Moneim AE [2016]: Selenium Nanoparticles Attenuate Oxidative Stress and Testicular Damage in Streptozotocin-Induced Diabetic Rats. Molecules 21, 1517. 
27. Kamani M, Mhabadi J A, Atlasi M A, Seyedi F, Kamani E, Nikzad H [2017]: Protective effect of alcoholic extract of garden cress seeds on the histopathological changes of the ventral prostate in streptozotocin diabetic rats. Int $\mathrm{J}$ Morphol 35[3]:1178-1184.

28. Banerjee S, Banerjee PP, Brown TR [2000]: Castration-induced apoptotic cell death in the brown Norway rat prostate decreases as a function of age. Endo 141 [2]: 821-832.

29. Hussein Y [2009]: Structural Changes in the Ventral Lobe of the Prostate of Diabetic Rat. Egyptian Journal of Anatomy 32[1-2]:105-113.

30. Felix-Patrício B, Miranda AF, Medeiros JL, Gallo CBM, Gregório BM, de Souza DB, Costa WS, Sampaio FJB [2017]: The prostate after castration and hormone replacement in a rat model: structural and ultrastructural analysis. Int Braz J Uro 43[5]: 957-965.

31. Ribeiro DL, Taboga SR, Goes RM [2009]: Diabetes induces stromal remodelling and increase in chondroitin sulphate proteoglycans of the rat ventral prostate. Int J Exp Pathol 90[4]: 400-11.

32. Hasnan J, Yusof MI, Damitri TD, Faridah AR, Adenan AS, Norbaini TH [2010]: Relationship between apoptotic markers [Bax and Bcl-2] and biochemical markers in type 2 diabetes mellitus. Singapore Med J. 51[1]:50-5.

33. Tian W, Lei H, Guan R, Xu Y, Li H, Wang L, Yang B, Gao Z, Xin Z [2015]: Icariside IIameliorates diabetic nephropathy in streptozotocin-induced diabetic rats. Drug Design, Development and Therapy 9: 5147-5157.

34. Zup L, Forger G [2002]: Testosterone regulates BCL-2 immunoreactivity in a sexually dimorphic motor pool of adult rats. Brain Res 950:312-6.

35. Gobbo MG, Ribeirro DL, Taboga SR, Alves de almeido E, Goes RM [2012]: Oxidative stress markers and apoptosis in the prostate of diabetic rats and the influence of vitamin $\mathrm{C}$ treatment. Journal of cellular biochemistry 113: 2223-2233.

36. Bahey NG, Soliman GM, El-Deeb TA, El-Drieny EA [2014]: Influence of insulin and testosterone on diabetic rat ventral prostate: Histological, morphometric and immunohistochemical study. Journal of Microscopy and Ultrastructure 2: 151160.

37. Liu H, Wang S [2005]: Study on the expression of androgen receptor in testis, epididymis and prostate of adult rats with diabetes. Zhonghua NanKe Xue 11:891-4.
38. Maghsoudi Z [2016]: The role of flax seed in prevention and management of diabetes mellitus type I and type II. Diab Obes Metab Disor OA 2: $7-11$.

39. Bernacchia R, Preti R and Vinci G [2014]: Chemical Composition and Health Benefits of Flaxseed. Austin J Nutri Food Sci 2[8]: 1045.

40. Hussein J, El-Khayat Z, Taha M, Morsy S, Drees E, Khateeb S [2012]: Insulin resistance and oxidative stress in diabetic rats treated with flaxseed oil. J. Med. Plants Res 6[42]: 5499-5506.

41. Maghsoudi Z [2016]: The role of flax seed in prevention and management of diabetes mellitus type I and type II. Diab Obes Metab Disor OA 2: 7-11.

42. Hendawi MY, Alam RTM, Abdellatief SA [2016]: Ameliorative effect of flaxseed oil against thiacloprid-induced toxicity in rats: hematological, biochemical, and histopathological study. Environ Sci Pollut Res 23:11855-11863.

43. Alachaher FZ, Dali S, Dida N, Krouf D [2018]: Comparison of phytochemical and antioxidant properties of extracts from flaxseed [Linum usitatissimum] using different solvents. IFRJ 25[1]: $75-82$.

44. Abidi A, Serairi R, Kourda N, Ben Ali R, Ben Khamsa S, Feki M [2016]: Therapeutic effect of flaxseed oil on experimental pulmonary fibrosis induced by bleomycin in rats. European Journal of Inflammation: 1-11.

45. Kaur P, Waghmare R, Kumar V, Rasane P, Kaur S, Yogesh Gat Y [2018]: Recent advances in utilization of flaxseed as potential source for value addition. OCL 25[3]: A304.

46. Elimam H, Ramadan BK [2018]: Comparative Study of the Possible Prophylactic and Curative Effects of Flaxseed Oil on the Lipid Profile and Antioxidant Status of Hyperlipidaemic Rats. J Appl Pharm 10 [1]: 257.

47. Mohamed DA, Rashed MM, Shallan M, Fouda K, Hanna LM [2016]: Amelioration of Benign Prostate Hyperplasia in Rats through Plant Foods. IJPPR 8 [12]: 2063-2070.

48. Mohammadi F, Nikzad H, Taherian A, Mahabadi JA, Salehi M [2013]: Effects of Herbal Medicine on Male Infertility. Anatomical science 10[4]:3-16.

49. Carotenuto F, Minieri M, Monego G, Fiaccavento R, Bertoni A, Sinigaglia F, Vecchini A, Carosella L, Paolo Di Nardo P [2013]: A diet supplemented with ALA-rich flaxseed prevents cardiomyocyte apoptosis by regulating caveolin-3 expression. Cardiovascular Research 100, 422-431. 
50. Razi SS, Latif MJ, Li X, Afthinos JN, Ippagunta N, Schwartz G, Sagalovich D, Belsley SJ, Connery CP, Jour G, Christofidou-Solomidou M, Bhora FY [2011]: Dietary flaxseed protects against lung ischemia reperfusion injury via inhibition of apoptosis and inflammation in a murine model. $\mathrm{J}$ Surg Res 171[1]:e113-21.

51. Dusane MB and Joshi BN [2013]: Beneficial effect of flax seeds in streptozotocin [STZ] induced diabetic mice: isolation of active fraction having islet regenerative and glucosidase inhibitory properties. Canadian Journal of Physiology and Pharmacology 91 [5]: 325-331.

52. Kadhim EF [2017]: Effect of Flaxseed Application on Bone Healing in Male Rats, Histological and Immunohistochemical Evaluation of Vascular Endothelial Growth Factor. J Med Sci 17 [2]: 81-88.

53. Nordina NS, Isab LM, Idida SZ, Lestaric W, Mustafac BE, Ikhwanc SJA, Darnisd DS, Kannane TP, Ahmade A, Mokhtarc KI [2017]: Study On Flaxseed Crude Extract On Stem Cells From Human Exfoliated Deciduous Teeth [SHED]. 1ST IIUM INTERNATIONAL DENTAL CONFERENCE, ABSTRACT ID: 26.

54. Kwon O, Xin L [2014]: Prostate epithelial stem and progenitor cells. Am J Clin Exp Urol 2[3]:209218. 
الملخص العربى

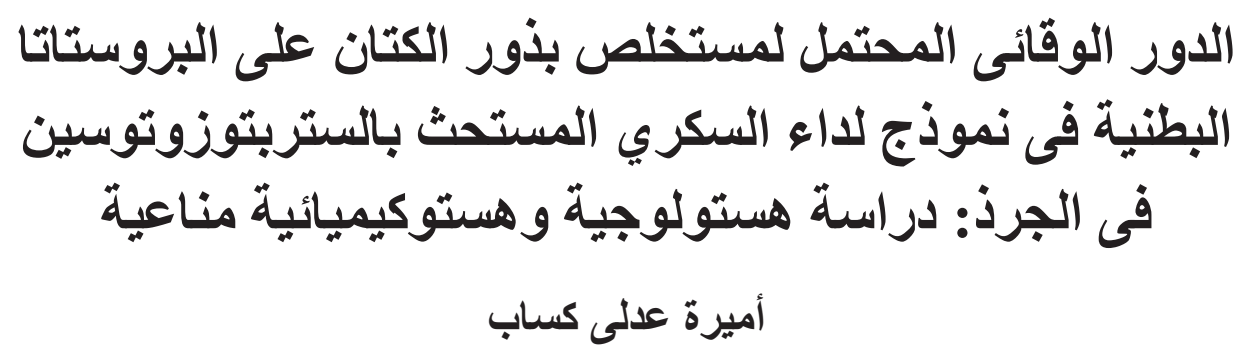

قسم الهستولوجيا_كلية الطب- جامعة طنطا

المقدمة: داء السكري هو اضطر اب مزمن يمكن أن يؤثر على الجهاز التناسلي مما يؤدي إلى خلل في الخصوبة. تلعب البروستاتا دورًا مهمًا في التكاثر وهو هدف متكرر لمضاعفات مرض السكري. بذور الكتان بديل واعد في العديد من الأمر اض المزمنة بسبب فو ائده الصحية. كما أن لها دور مقترح في السبطرة على مرض السكري بسبب أنشطتها الدو ائية و اسعة النطاق. الهدف من البحث: تقييم الدور الوقائي المحتمل لمستخلص بذور الكتان على غدة البروستاتا البطنية في الجرذان المصابة بداء السكري.

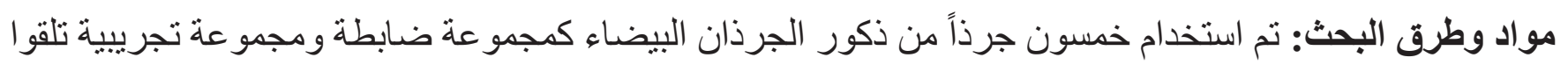
حقنة واحدة داخل الغشاء البريتونى من الستربتوزوتوسين (•7 مجم / كجم). وقسمت الجرذان التجريبية المصابة بمرض السكري المؤكد إلى: المجموعة المصابة بالسكري والتي ظلت بدون معالجة ومجموعة السكري - بذور

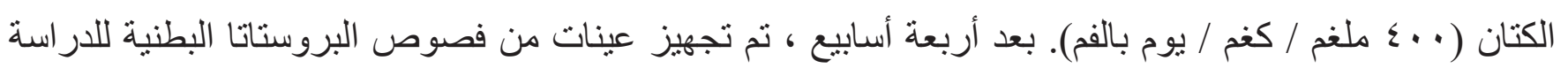

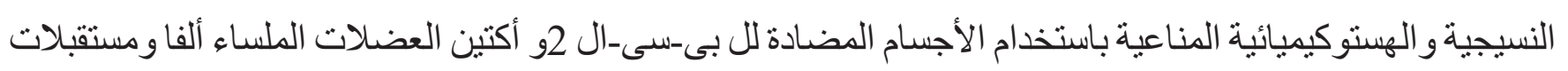

الاندروجين. النتائج: وبالمقارنة بالمجمو عة الضابطة، أظهرت عينات مجمو عة السكري ضمور طلائي غدي مع سماكة السدى الليفي العضلي. وقد لوحظ انخفاض فى ارتفاع الخلايا الظهارية و انخفاض ملحوظ من الناحية الإحصائية في التفاعل المناعى لل بى-سى-ال r في الخلايا الظهارية.كما شو هد زيادة ذات دلالة إحصائية في ألياف الكو لاجين و فى التفاعل المناعى لأكتين العضلات الملساء ألفا في السدى. كمل لوحظ وجود انخفاض بشكل ملحوظ فى التفاعل المناعى لمستقبلات الاندروجين في كل من الخلايا الظهارية و السدى. وفي المقابل ، ظهرت تغييرات قليلة في مجموعة السكرى- بذور الكتان التي تلقت مستخلص بذور الكتان. الاستنتاج: داء السكري سبب تغييرات تركيبية في غدة البروستاتا البطنية للجرذان. مستخلص بذور الكتان خفف من هذه التأثير ات وحافظ جزئيا على تركيب الغدة. 